SCADidoc

International Journal of Dentistry and Oral Science (IJDOS)

ISSN: 2377-8075

\title{
Genetic Association Of Bcl2 (rs2279115) Gene Polymorphism With Susceptibility To Oral Cancer - A Case Control Study In South Indian Population
}

Research Article

Mithra. $S^{1 *}$, Vijayashree Priyadharshini ${ }^{2}$, Pratibha Ramani ${ }^{3}$

${ }^{1}$ Department of Oral and Maxillofacial Pathology, Saveetha Dental College and Hospitals, Saveetha Institute of Medical and Technical Sciences (SIMATS), Saveetha University, Chennai, India.

${ }^{2}$ Assistant Professor, BRULAC-DRC, Saveetha Dental College \& Hospital, Saveetha Institute of Medical and Technical Sciences (SIMATS), Saveetha University, Chennai, India.

${ }^{3}$ Professor \& Head, Department of Oral and Maxillofacial Pathology, Saveetha Dental College and Hospitals, Saveetha Institute of Medical and Technical Sciences (SIMATS), Saveetha University, Chennai, India.

\section{Abstract}

Background: Oral cancer is now one of the most serious health issues faced by mankind. The anti-apoptotic protein Bcl2 is one of the most common anti-apoptotic proteins found in OSCC. They play a role in the growth of cancer and mediate resistance to existing anticancer therapies.

Aim: To investigate the genetic association of Bcl2(rs2279115) gene polymorphism with susceptibility to oral cancer - a case control study in the south Indian population.

Materials \& Methods: About $5 \mathrm{ml}$ of venous blood was collected from OSCC patients $(\mathrm{n}=21)$ and controls $(\mathrm{n}=25)$. DNA extraction was performed using a buffy coat obtained from EDTA anti-coagulated blood following the protocol by Miller et al (1988) salting out method. Genotyping was performed by PCR-RFLP method.

Results: The genotype and allele frequency for the polymorphism studied was almost similar in both case and control groups returning an insignificant $\mathrm{p}$ value between the two groups. The major limitation of the study is the small sample size.

Conclusion: $B c l 2$ ( $r s 2279115)$ gene polymorphisms could be a potential genetic marker as confirmed from other studies across different populations. Recruiting more patients from different ethnic groups could indeed provide clues on the possible association of $\mathrm{Bcl} 2$ polymorphism with OSCC.

Keywords: Bcl-2; Carcinogenesis; Oral Cancer.

\section{Introduction}

Oral cancer is the most prevalent neoplasm of head and neck, with $95 \%$ being oral squamous cell carcinoma globally [1]. The prevalence of all oral cancers has escalated in past few decades. Of all the cancers of head and neck, oral cancer is known to have poor prognosis and mortality despite the advancements in the treatment modalities $[2,3]$. The development of oral cancer is a multistep process in which malignant changes evolve over time as a result of the accumulation of numerous genetic mutations within cells. Hyperplastic disorders, dysplastic cellular appearance, unorganised deregulated cell formation, and eventually carcinoma are all caused by these genetic mutations $[3,4]$. The oral cancers, especially oral squamous cell carcinoma decreases the survival rate at later stages of malignancy. So, early diagnosis of cancers is important for determining the prognosis and recurrence. The detection of abnormal gene expressions and changes at the molecular level would greatly aid in the early diagnosis of oral cancer. The significant proportion of cancers is caused by a deviation in the direction of programmed cell death (apoptosis), which can result in tumour pathogenesis and progression. B-cell lymphoma/ leukemia-2 $(\mathrm{Bcl} 2)$ is an anti-apoptotic protein which is a part of the regulatory system that controls the cell cycle and the induction of apoptosis. The core of the apoptotic programme and the main effectors arm of the cell death programme are the $\mathrm{Bcl}-2$ gene family and related proteins. Unlike most other oncogenes that facilitate cell cycle progression, the bcl-2 oncogenes was discovered to

*Corresponding Author:

Dr. Mithra.S,

Department of Oral and Maxillofacial Pathology, Saveetha Dental College and Hospitals, Saveetha Institute of Medical and Technical Sciences (SIMATS), Saveetha University,

Chennai, India.

E-mail: mithraswornappan@gmail.com

Received: April 20, 2021

Accepted: July 09, 2021

Published: July 19, 2021

Citation: Mithra.S, Vijayashree Priyadharshini, Pratibha Ramani. Genetic Association Of Bcl2 (rs2279115) Gene Polymorphism With Susceptibility To Oral Cancer - A Case Control Study In South Indian Population. Int J Dentistry Oral Sci. 2021;8(7):3431-3434. doi: http://dx.doi.org/10.19070/2377-8075-21000698

Copyright: Mithra.S ${ }^{\circ} 21$. This is an open-access article distributed under the terms of the Creative Commons Attribution License, which permits unrestricted use, distribution and reproduction in any medium, provided the original author and source are credited. 
protect cells from undergoing apoptosis in response to a variety of stimuli [4].

Previous literature have identified genetic alterations in Bcl-2 leading to different carcinomas. Muzio et al, found that it is possible to suggest bcl-2 as an early marker of prognosis in oral squamous cell carcinoma [7]. Sulkowska et al, hypothesised potential links between $\mathrm{Bcl}-2$ protein expression and OSCC clinic pathological features [8]. They have particularly evaluated OSCC rather than all oral cancers in Indian population. The aim of this research is to identify the Genetic alteration in bcl2 family of genes and their putative association with oral cancers in south Indian population.

\section{Materials And Methods}

\section{Sample selection}

All the samples for the current study are selected based on the WHO/ISH guidelines. Clinical investigations were carried out by qualified physicians and informed consent was obtained from all the patients and controls. About $5 \mathrm{ml}$ of blood sample was collected from oral cancer patients $(n=21)$ and control $(n=25)$ between the age group of 20 and 65 years. Patients' samples were collected from Saveetha Dental College and Hospitals, Saveetha University (SIMATS). Patients with other systematic diseases were excluded from the study. The study was approved by the Institutional $\mathrm{Hu}-$ man Ethical Committee.

\section{Genotyping}

Genomic DNA was extracted from the buffy coat of EDTA anti-coagulated blood using the Miller et al. (1988) salting out method [9]. Genotype analysis for the SNP marker was based on PCR-RFLP method. PCR was performed in $20 \mu \mathrm{l}$ volumes using $100 \mathrm{ng}$ of genomic DNA as template, using primers, BCL2-F: 5'-GCGCTCGGCACCGGCGG-3' and BCL2-R: 5'-GGCAGCGGCGGCGGCAG-3' (Eurofins MWG Operon, Bangalore, India). The segment of $\mathrm{Bcl} 2$ gene spanning the polymorphism was amplified following PCR conditions, which involved an initial denaturation at $94^{\circ} \mathrm{C}$ for $5 \mathrm{~min}$, denaturation at $94^{\circ} \mathrm{C}$ for $35 \mathrm{sec}$, annealing at $55^{\circ} \mathrm{C}$ for $35 \mathrm{sec}$, extension at $72^{\circ} \mathrm{C}$ for $35 \mathrm{sec}$, and a final extension at $72^{\circ} \mathrm{C}$ for $5 \mathrm{~min}$. About $5 \mu \mathrm{l}$ of PCR product was checked on a 1.5\% agarose gel (Fig. 1A). 15 $\mu \mathrm{l}$ of PCR product was digested using BccI restriction enzyme procured from New England Biolabs, England. Digestion was carried out at $37^{\circ} \mathrm{C}$ for $2 \mathrm{~h}$. The digested product was visualized on a $2 \%$ agarose gel and the results were documented (Fig. 1B). Comparison of allele frequencies between different ethnic groups was performed from the data obtained from Ensembl genome browser [10].

\section{Statistical analysis}

The mean and standard deviation of continuous variables were calculated. The Student's t-test was used to compare the means of various variables. The Chi-square test was used to see whether the genotype distribution deviated from Hardy-Weinberg equilibrium and whether there were any major variations in allele or genotype frequencies between the cases and controls. The relationship between genotypes and oral cancer was investigated using the odds ratio (OR) with a 95\% confidence interval (95 percent $\mathrm{CI}$ ). The statistical package SPSS 14.0 version (SPSS Inc., Chicago, Illinois, USA) was used to conduct statistical tests, including logistic regression analysis. Statistical significance was described as a $\mathrm{p}$ value of less than 0.05 .

\section{Results}

High molecular weight genomic DNA was isolated from the patients and control subjects (Figure 1). In vitro amplification of the gene of interest spanning the polymorphic site in the $\mathrm{Bcl} 2$ gene was performed under controlled conditions, which yielded amplicon of size $300 \mathrm{bp}$ (Figure 2). Genotyping was performed using the RFLP approach. The enzyme used for the purpose was BccI, which cleaves the amplicon into 2 fragments of size $137 \mathrm{bp}$ and $163 \mathrm{bp}$ corresponding to the presence of A allele. An uncut $300 \mathrm{bp}$ product corresponds to $\mathrm{C}$ allele and the combination of both alleles (CA genotype) presents with 3 bands upon digestion with BccI (Figure 3). The genotype and allele frequency for the rs2279115 of $\mathrm{Bcl} 2$ gene was found to be similar between the case $(C=71 \%$ and $A=29 \%)$ and the control $(C=72 \%$ and $A=28 \%)$ groups. The genotype frequency of cases and controls did not differ significantly at two degrees of freedom returning a $p$ value of 0.955 , where 0.05 was considered to be statistically significant. Upon segregation of genotypes based on different models viz., dominant, recessive and additive, the $\mathrm{p}$ value remained insignificant in the present study group. The possible reason for such an observation could be attributed to small sample size. Increasing the sample size could aid in deriving possible association between the gene polymorphism and OSCC. A comparison of allele frequencies among different populations for the $B c l 2$ polymorphism showed that the allele frequency observed in the present study was similar to that observed in the south Asian population as identified from the database.

\section{Discussion}

Oral cancers are characterized by a combination of molecular events that increase the risk of the interaction of a person's genetic predisposition and exposure to carcinogens in the environment [11]. Tobacco, alcohol, oncogenes, viruses, and inflammation are all carcinogens that can alter individual genes as well as

Table 1. Genotype frequencies of Bcl2 rs2279115 gene polymorphism among the cases and controls.

\begin{tabular}{|c|c|c|c|c|c|c|}
\hline$*$ & CC & CA & AA & C & A & HWE (p value)* \\
\hline Case $(\mathrm{N}=21)$ & 12 & 6 & 3 & 0.71 & 0.29 & 0.169 \\
\hline Control $(\mathrm{N}=25)$ & 14 & 8 & 3 & 0.72 & 0.28 & 0.302 \\
\hline
\end{tabular}

*For departure from Hardy-Weinberg equilibrium (HWE), chi square with one degree of freedom. The genotype frequency of cases and controls do not differ significantly $\chi^{2} \mathrm{df}(\mathrm{P}=0.955)$. 
Table 2. Genotype distribution of the Bc12 rs2279115 gene polymorphism in cases and controls based on different models.

\begin{tabular}{|c|c|c|c|c|}
\hline \multicolumn{5}{|c|}{ Dominant } \\
\hline Genotypes & Case & Control & Unadjusted OR [95\% CI] & P value \\
\hline $\mathrm{CC}$ & 12 & 14 & 1.048 & \multirow{2}{*}{0.938} \\
\hline $\mathbf{C A}+\mathbf{A A}$ & 9 & 11 & [0.3249 - 3.3779] & \\
\hline \multicolumn{5}{|c|}{ Recessive } \\
\hline AA & 3 & 3 & 1.222 & \multirow{2}{*}{0.819} \\
\hline $\mathrm{CA}+\mathrm{CC}$ & 18 & 22 & {$[0.2195-6.8071]$} & \\
\hline \multicolumn{5}{|c|}{ Allele } \\
\hline $\mathrm{C}$ & 71 & 72 & 0.952 & \multirow{2}{*}{0.876} \\
\hline A & 29 & 28 & {$[0.5152-1.7595]$} & \\
\hline
\end{tabular}

Figure 1. High molecular weight human genomic DNA isolated from peripheral blood samples.

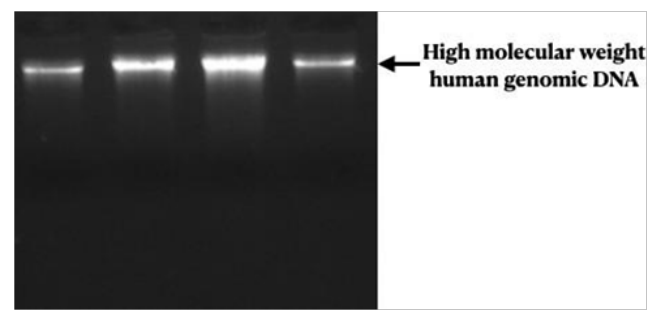

Figure 2. (A) Agarose gel electrophoretogram of BCL2 rs2279115 C/A polymorphism spanning region of size 300 bp (Lanes 1-3: Amplified product; M: 100 bp DNA ladder). (B) BccI digestion of PCR amplified product (Lanes 1, 2, 4, 5: Homozygous AA, Lanes 6-11: Heterozygous AC, Lane 3: Homozygous CC).

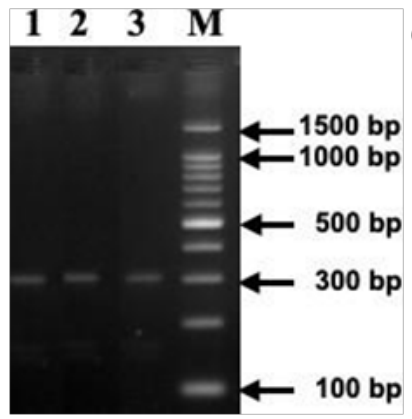

(a)

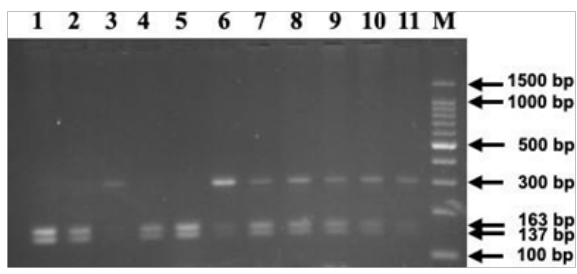

(b)

Figure 3. Comparison of allele frequencies of gene polymorphism among different populations with the present study group*.

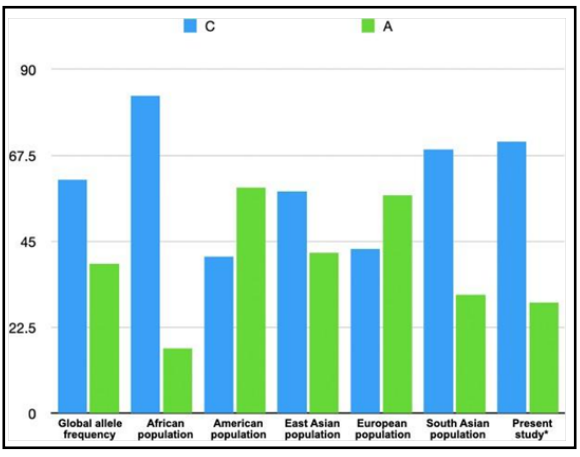

larger portions of the genetic material, including chromosomes. Multiple chromosomes and genes are affected by subsequent genetic damage, and the accumulation of these modifications tends to lead to carcinoma in certain cases, often via a clinically visible pre-malignant or potentially malignant lesion [12]. Activating mutations or amplification of oncogenes that encourage cell survival and proliferation, as well as inactivation of tumor suppressor genes that inhibit cell proliferation, are among the genetic changes [14]. While lifestyle factors play a significant role in aetiology, some patients tend to be predisposed due to an inherited trait that affects their ability or inability to metabolise carcinogens or pro-carcinogens, likely in combination with a reduced ability to repair DNA damage $[12,13]$.

Programmed cell death is called apoptosis which is a normal physiological process; but abnormal levels of apoptosis are potentially dangerous. Defects in apoptosis are predominating in multiple disorders, especially carcinomas [15]. The Bcl-2 protein family either promotes cell survival, initiates cell death, triggers the effector pathways of apoptosis or activate the effector path- 
ways of apoptosis [16]. High levels of Bcl-2 expression have been identified in a variety of solid tumours, not just haematological malignancies. Cingeetham et al, revealed that $\mathrm{Bcl} 2$ genotypes were significantly associated with increased risk for acute myeloid leukemia occurrence [19].

Also in recent decades the incidences of oral cancer have increased to a greater extent. Few researches have also attempted to estimate the correlation between $\mathrm{Bcl} 2$ mutations/polymorphisms in oral cancers. Dorjgochoo et al, observed associations between genetic variants in the $\mathrm{Bcl} 2$ gene and endometrial cancer risk. In human endometrial carcinoma tissues, BCL2 expression may be a sign of apoptosis inhibition [20]. Suri et al. performed immunohistochemistry to test the expression, as well as quantify and assess the strength and pattern of $\mathrm{Bcl}-2$ in various histological grades of OSCC. From well-differentiated to poorly differentiated OSCCs, the number of cells expressing Bcl-2 increased, showing an inverse association with differentiation [21]. Loro et al. used immunohistochemistry to identify the loss of $\mathrm{Bcl} 2$ in oral epithelial dysplasia and OSCC, which could be due to bcl-2 mutations. No mutations were discovered that could explain the loss of bcl2 in oral dysplasia and carcinoma [22]. Since the expression of the Bcl-2 oncogene is required for tumour development, Gibson et al. investigated the effect of anti-Bcl-2 ribozyme on the phenotype of oral cancer cells and discovered that anti-Bcl-2 activity was successful in the treatment of oral cancer [23]. Fernández-Mateos et al,found a significant correlation between $\mathrm{Bcl} 2$ gene and oral cavity cancer susceptibility. They also identified that the presence of $\mathrm{C}$ allele highly reduces the activity of $\mathrm{P} 1$ and $\mathrm{Bcl}-2$ protein expression; increasing apoptosis which indicates $\mathrm{Bcl} 2$ (rs2279115) polymorphism found in P2 gene promoter, acting as a negative regulator element, decreasing $\mathrm{P} 1$ promoter activity $[17,18]$.

The current research indicates that Bcl2 rs2279115 C/A polymorphism acts as an independent risk factor for oral cancer. Although we did not observe any significant change between the two groups in the present study, the study can be extended to a large number of samples of different grades and from different populations. Since the distribution of $B c l 2$ (rs2279115) gene polymorphisms were in concordance with the Hardy-Weinberg equilibrium, the results of this study are unlikely to be biased. The major limitation of the study is considered to be the sample size.

\section{Conclusion}

The present study demonstrates the possible association of $\mathrm{Bcl} 2$ gene polymorphism with oral cancer. Although not significant, other variants in $B c l 2$ gene can be investigated further to identify potential drivers of $B c l 2$ gene in relation to oral cancer.

\section{References}

[1]. Ayaz B, Saleem KH, Azim WA, Shaikh AL. A clinico-pathological study of oral cancers. Biomedica. 2011 Jan;27(1):29-32

[2]. Juliana Noguti, Carolina Foot Gomes De Moura, Gustavo Protasio Pacheco De Jesus, Victor Hugo Pereira Da Silva, Thais AyakoHossaka, Celina Tijuko Fujiyama Oshima, et al. Cancer Genomics \& Proteomics.2012 Sep 9; (5) 329-335.
[3]. Jaikumarr Ram A, Girija As S, Jayaseelan VP, Arumugam P. Overexpression of BASP1 Indicates a Poor Prognosis in Head and Neck Squamous Cell Carcinoma. Asian Pac J Cancer Prev. 2020 Nov 1;21(11):3435-3439. PubmedPMID: 33247706.

[4]. Aparna J, Smiline-Girija AS, Paramasivam A, Vijayashree-Priyadharsini J. Deciphering the genetic alterations in matrix metallo-proteinase gene family and its putative association with head and neck squamous cell carcinoma. MolBiol Res Commun. 2021 Mar;10(1):13-22. PubmedPMID: 33681393.

[5]. Tanaka T, Ishigamori R. Understanding carcinogenesis for fighting oral cancer. J Oncol. 2011;2011:603740. Pubmed PMID: 21772845.

[6]. Arumugam J, Jeddy N, Ramamurthy A, Thangavelu R. The expression of $\mathrm{Bcl}-2$ in oral squamous cell carcinoma-A review. Journal of Orofacial Sciences. 2017 Jul 1;9(2):71.

[7]. Lo Muzio L, Falaschini S, Farina A, Rubini C, Pezzetti F, Campisi G, et al. $\mathrm{Bcl}-2$ as prognostic factor in head and neck squamous cell carcinoma. Oncol Res. 2005;15(5):249-55. PubmedPMID: 16261844.

[8]. Sulkowska M, Famulski W, Sulkowski S, Reszeć J, Koda M, Baltaziak M, et al. Correlation between $\mathrm{Bcl}-2$ protein expression and some clinicopathological features of oral squamous cell carcinoma. Pol J Pathol. 2003 Jan 1;54(1):49-52

[9]. Miller SA, Dykes DD, Polesky HF. A simple salting out procedure for extracting DNA from human nucleated cells. Nucleic Acids Res. 1988 Feb 11;16(3):1215. PubmedPMID: 3344216.

[10]. Hunt SE, McLaren W, Gil L, Thormann A, Schuilenburg H, Sheppard D, et al. Ensembl variation resources. Database (Oxford). 2018 Jan 1;2018:bay119. PubmedPMID: 30576484.

[11]. Califano J, van der Riet P, Westra W, Nawroz H, Clayman G, Piantadosi $S$, et al. Genetic progression model for head and neck cancer: implications for field cancerization. Cancer Res. 1996 Jun 1;56(11):2488-92. PubmedPMID: 8653682

[12]. Scully C, Field JK, Tanzawa H. Genetic aberrations in oral or head and neck squamous cell carcinoma (SCCHN): 1. Carcinogen metabolism, DNA repair and cell cycle control. Oral Oncol. 2000 May;36(3):256-63. PubmedPMID: 10793327.

[13]. Jain A, Selvi SG, Arumugam P, Jayaseelan VP. A Computational Approach to Identify the Mutations in the Genes of the RTK Signaling Pathway and their Possible Association with Oral Squamous Cell Carcinoma. Middle East Journal of Cancer. 2021 Jan 1;12(1):1-9.

[14]. Choi S, Myers JN. Molecular pathogenesis of oral squamous cell carcinoma: implications for therapy. J Dent Res. 2008 Jan;87(1):14-32. PubmedPMID: 18096889.

[15]. Hotchkiss RS, Strasser A, McDunn JE, Swanson PE. Cell death. N Engl J Med. 2009 Oct 15;361(16):1570-83. PubmedPMID: 19828534.

[16]. Kelly PN, Strasser A. The role of Bcl-2 and its pro-survival relatives in tumourigenesis and cancer therapy. Cell Death Differ. 2011 Sep;18(9):141424. PubmedPMID: 21415859.

[17]. Fernández-Mateos J, Seijas-Tamayo R, AdansaKlain JC, Pastor Borgoñón M, Pérez-Ruiz E, Mesía R, et al. Genetic Susceptibility in Head and Neck Squamous Cell Carcinoma in a Spanish Population. Cancers (Basel). 2019 Apr 7;11(4):493. PubmedPMID: 30959967.

[18]. Lehnerdt GF, Franz P, Bankfalvi A, Grehl S, Kelava A, Nückel H, et al. The regulatory BCL2 promoter polymorphism $(-938 \mathrm{C}>\mathrm{A})$ is associated with relapse and survival of patients with oropharyngeal squamous cell carcinoma. Ann Oncol. 2009 Jun;20(6):1094-9. PubmedPMID: 19196738.

[19]. Cingeetham A, Vuree S, Dunna NR, Gorre M, Nanchari SR, Edathara PM, et al. Influence of BCL2-938C $>$ A and BAX-248G $>A$ promoter polymorphisms in the development of AML: case-control study from South India. Tumour Biol. 2015 Sep;36(10):7967-76. PubmedPMID: 25957891.

[20]. Dorjgochoo T, Xiang YB, Long J, Shi J, Deming S, Xu WH, et al. Association of genetic markers in the BCL-2 family of apoptosis-related genes with endometrial cancer risk in a Chinese population. PLoS One. $2013 \mathrm{Apr}$ 23;8(4):e60915. PubmedPMID: 23637776.

[21]. Suri C. The immunohistochemical evaluation of the expression of BCL-2 in different histological grades of squamous cell carcinoma. J ClinDiagn Res. 2009;3(6):1891-99.

[22]. Loro LL, Johannessen AC, Vintermyr OK. Loss of BCL-2 in the progression of oral cancer is not attributable to mutations. J ClinPathol. 2005 Nov;58(11):1157-62. PubmedPMID: 16254104.

[23]. Gibson SA, Pellenz C, Hutchison RE, Davey FR, Shillitoe EJ. Induction of apoptosis in oral cancer cells by an anti-bcl-2 ribozyme delivered by an adenovirus vector. Clin Cancer Res. 2000 Jan;6(1):213-22. PubmedPMID: 10656452. 